\title{
The Application of Situational Teaching Method to English Teaching in Primary Schools
}

\author{
Yafen $\mathrm{Hu}$ \\ Ningbo Dahongying University \\ Ningbo, China
}

\begin{abstract}
Situational approach is widely used in English teaching. Up to now it has great achievements in the English teaching of primary schools. Under the circumstances, based on a teaching experiment and a questionnaire survey, the author is to discover the main points we should pay attention to when applying the situational teaching method to English teaching in primary schools. Focusing on primary school English teaching, this study aims to explore how to create effective situational teaching approach in primary school English learning by creating effective situations, such as intuitive teaching method, the description method, the using of multimedia, the play method, the song method. The research results showed that situational teaching method is valuable to English teaching and learning.
\end{abstract}

Keywords—situational teaching method; English teaching; primary school

\section{INTRODUCTION}

Part 1 covers the research background, research purpose, significance of the study and the outline of the thesis.

\section{A. Research Background}

English as an international language has been widely used. The importance of English-learning has become more and more obvious, and the elementary school English as English-learning enlightenment has increasingly become the focus of our attention. At the same time, along with the further implementation of quality-oriented education and the new curriculum standard, stimulating students' interest in relaxed learning, enhancing practical ability and innovative spirit have become the goal of primary school education. So under the circumstances, how to use situational teaching method more efficiently is particularly important. This paper discusses on the main point we should pay attention to of present application situational teaching method and how to solve these problems to use situational teaching method more tactfully.

\section{B. Research Purpose and Significance of the Study}

A language should be learned in a real situation in order to learn it well. The pupils are good at imitating, have keen sense of hearing and good ideation of specific images, and they cannot pay long attention to things intentionally. However, the situational teaching method emphasizes the real scene of language learning and regarding the scene as the center. Teachers could set situation that is closely related to the teaching content for students according to the cognitive rule and learning ability of students in primary school, through a variety of ways and auxiliary tool Therefore situational teaching method is quite suitable for pupils especially the students in lower grades who are good at imitating, have keen sense of hearing and good ideation of specific images, and cannot pay long attention to things intentionally too study language. This paper solve the problem of situational teaching in the actual teaching process and implement the teaching method more tactfully, which can enhance the pupils' interest, enliven the atmosphere of class, and improve pupils' thinking ability, thus use primary school English teaching effectively.

\section{Outline of the Thesis}

This thesis is divided into three parts as follows: Part 1 emphasizes the studies on situational teaching method. In this part, the improvement, achievements and limitations are pointed out. Part 2 is about the research method. Part 3 is the results and discussion. It provides the main points we should pay attention to when we apply the situational teaching method and implement measures effectively of situational teaching method. It is the key part of the whole paper. Part 4 is the conclusion about the paper. Then the findings of the study, the implications, the limitations and the suggestions are set out, which will have some enlightenment on primary English teaching.

\section{LITERATURE REVIEW OF SitUATIONAL TEACHING METHOD AT ABROAD AND HOME}

In the 1920s and 1930s applied linguists of Britain originally put forward the concept of situational language teaching in their work. Since the time, many eminent applied linguists have made the stand method be the fundamental methodology in the realm of language teaching. This method existed for a very long period. And it has formed the design which is being adopted extensively as before.

In the 1960s, George Pittman from Australia was considered one of the most animated advocates situational language teaching of the period. According to situational method, George Pittman and his co-workers developed a group of teaching materials. Because of their influence, these teaching materials were implemented throughout Australia, New Guinea, and the Pacific territories. 
An influential set of essay about situational approach written by Hornby was published in English Language Teaching in 1950. And in 1983, he made a comment on this method: "This method is widely used at the time of writing and a very large number of textbooks are based on it". Consequently, the concepts of structural situational approach and situational language teaching were used very commonly.

Such educators as Socrates, Rousseau, Dewey, Sukhomlinskii, advocate and practice situational teaching method. Their education treatise and teaching practice has the precious experiences and profound lessons on situational teaching. The ancient Greek education Socrates was engaged in teaching, often creating a certain situation for students. He inspired students by creating situation to inspire students to seek knowledge. The American educator Dewey also attaches great importance to situational teaching, and he (1938) argues that there must be a practical experience as the beginning of thinking. It was Dewey who first applied the theory of situational language teaching to the practice of language teaching. He attributed thinking to immediate situations. In addition, he held that students should study through practice and discover knowledge points by themselves. Only in this way can students learn in an active and vigorous cultural circumstance. He put forward fivestep-thinking, five-step-teaching, meaning that students think and solve problems after five steps: situation-problemgrasping data-presupposition-checking. This indicates that in order to encourage students to think independently, the teacher should create problem-situation first. After that, the students can check their thinking. In the course of teaching, it is necessary to set up a situation and make teaching plan according to the purpose of teaching situation. The teacher uses the situation to arouse students' learning motivation, implement teaching plan and evaluate teaching results. In previous study, Richard, J.C. and Rodgers, T.S. scholars have a preliminary exploration of the theory and practice of situational teaching. Brumfit (1983) in his research also has a further analysis of situational teaching method.

In the modern teaching thought, the form of situational teaching is reflected systematically. For example, the teaching thought of Sukhomlinskii is attached great importance to the education function of the natural situation. He often takes her children to nature, let them experience the beauty of nature, so that students can learn knowledge in a relaxed atmosphere, stimulate students' interest in learning and develop students' imagination and aesthetic ability. In order to achieve this goal, Sukhomlinskii has produced 300 pages of nature books for children, each page gives children a great interest and vivid image of objective things. I think it is a good measure, but in my paper I will find more efficient measures.

J. B. Carrol (1964), an American scholar, argues that learning a foreign language should be based on understanding, allowing students to practice in actual life and communicative situations, and to develop logical memory in practice. Language and situation combine to create a learning process similar to language acquisition. Learning English is just like children learning to speak. They should learn spoken
English in a situation first, and then learn written English. So, it is vital for children to study in a situation.

The study of situational teaching in China began in 1978 with the experiment of the situational teaching method in $\mathrm{Li}$ Jilin. So far, situational teaching research has achieved fruitful results. In the aspect of theory, $\mathrm{Li}$ (1990) is the author of the situational teaching experiment and research. She stated the theory of situational language teaching and some related evidences about the theory. Furthermore, she also thought about the modes and principles of situational language teaching, the application of situational language teaching in reading and writing. It should be said that situational teaching research made a huge contribution to education in our country, the research will also continue to deepen, as Wang (2005) said "situational teaching is developing continuously, inevitably will continue to have a new development." How to develop the method efficiently? There is very little information on it.

Practice makes perfect. The more skills the students learn from the teacher, the more they know how to use a foreign language. The focus of situational language teaching lies on the need to practice language in meaningful situation-based activities. Hence, situational language teaching becomes prevailing over the word's teaching arena in recent decades.

Great achievement has been made in the field of situational language teaching, which promotes the development of education worldwide. There are many ways to create situations. For example, a situation can be created by means of realia, with body language, stick figures, pictures, story etc. As Li Jilin said, the principles of situation creating were practical, explicit, communicative, interesting, inspiring and creative.

To sum up, most of the above studies are conducted on learners or college students, and very few have been done on primary school students, so whether it is applicable to primary school students remains to be further investigated; Is there a more effective way to apply situational teaching method to primary English teaching?

Therefore this paper is in order to answer these questions.

\section{RESEARCH DESIGN}

\section{A. Research Questions}

The study aim to investigate situational teaching method by answering the following questions: What's the necessity of situational teaching method? What main points should we pay attention to in the application of situational teaching method? Is there a more effective way to apply situational teaching method to primary English teaching?

\section{B. Research Methods}

We set a control group, while controlling other variables to compare the participants who are taught by situational teaching method with those who are not taught by situational teaching method. The period of teaching experiment starts from March 5, 2018 and ends on May 5, 2018. The class is for 90 minutes a week for each class. 
The participants in the observation on the classroom teaching are primary students who are 10-11 years old in each class but their English level is similar. And the teacher is a University student. For the detailed information for the two classes, please see "Table I".

TABLE I. BACKGROUND INFORMATION OF PARTICIPANTS

\begin{tabular}{|c|c|c|c|c|c|}
\hline \multirow{2}{*}{$\begin{array}{l}\text { Students } \\
\text { Level }\end{array}$} & \multirow[t]{2}{*}{ Class } & \multirow[t]{2}{*}{ Class Size } & \multicolumn{2}{|l|}{ Gender } & \multirow{2}{*}{$\begin{array}{l}\text { Use the situational } \\
\text { teaching method or not }\end{array}$} \\
\hline & & & Female & Male & \\
\hline Grade 4 & 1 & 30 & 18 & 12 & Yes \\
\hline Grade 4 & 2 & 32 & 15 & 17 & No \\
\hline
\end{tabular}

Then we apply the situational teaching methods to experimental group Class 1 in different ways, such as intuitive teaching method, the description method, the using

of multimedia, the play method and the song method. But for the control group Class 2, we only use the traditional teaching methods instead of the situational teaching methods.

TABLE II. QUESTIONNAIRE FOR THE STUDENTS

\begin{tabular}{|c|c|c|}
\hline Class & 1 (Experimental Group) & 2 (Control Group) \\
\hline Can you participate in the class well? & $\hat{\sim} \hat{\gamma}$ & 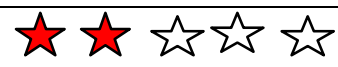 \\
\hline Can you master the grammar well? & 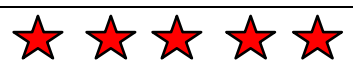 & 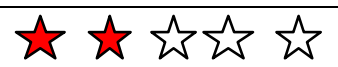 \\
\hline Can you master the vocabulary well? & $\hbar \hbar$ & 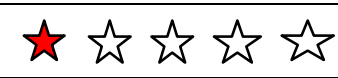 \\
\hline Can you focus on the class well? & 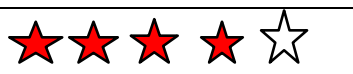 & 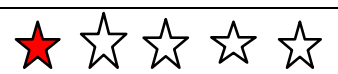 \\
\hline Do you like the method of teaching? & & 崖全食 \\
\hline
\end{tabular}

TABLE III. QUESTIONNAIRE FOR THE TEACHERS

\begin{tabular}{|c|c|c|}
\hline Class & 1 (Experimental Group) & 2 (Control Group) \\
\hline Degree of participation & 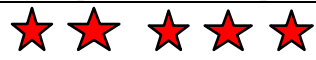 & 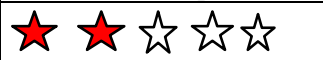 \\
\hline Interactive Rate & 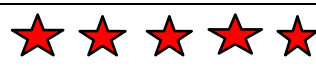 & 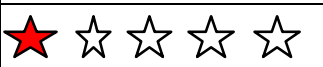 \\
\hline Classroom Atmosphere & 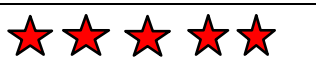 & 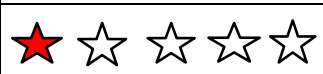 \\
\hline Accuracy of homework & 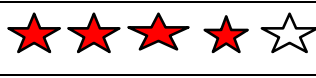 & 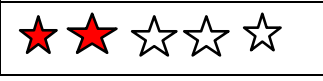 \\
\hline
\end{tabular}

After the two months' experiment, a questionnaire was administered among the students so that we can know the students' level of satisfaction. And though the questionnaire for teachers it is expected to know the students' mastery of knowledge and the students' participation. They should color the star to show their answer. "Table II" is the final result of the students questionnaire and "Table III" is the final result of the teacher's questionnaire.

As you can see, according to the results above, it is clear that under the situational teaching method, students' learning interest and learning ability are much higher that those who are under the traditional teaching method.

\section{RESUlTS AND DISCUSSION}

Part 4 is to answer the research questions: What's the main point of situational teaching method? Is there a more effective way to apply situational teaching method to primary English teaching?
Based on the teaching experiment, the following sections will discuss the results of the analysis and answer the research method.

\section{A. The Main Points We Should Pay Attention to}

1) Focus on the language usage environment: In English learning, many students will find it boring. In the actual situation of teaching, teachers should build more specific language environment for students, so ensure that the students in the specific language situation of grammatical structures, grammatical rules, application, deepen students' understanding of the grammar knowledge. In addition, in the process of creating a situation, teachers should also pay attention to the fact that it is in line with the actual situation, so as to make students more likely to accept it.

2) Flexible teaching situations: In the process of creating the teaching situation, it should be based on different grammatical content. The teachers should select 
and create situation flexibly, and use the appropriate teaching situation to arouse the students' interests and curiosity. Thus, students can enter into the situation to experience and learn. But for some complicated and difficult grammar knowledge and grammatical structure, we could use inductive way and deductive method to create situational teaching situations, so as to achieve better teaching results.

3) To highlight the dominant status of students: The students play the main role in the class. Situational teaching method is the key to highlight the dominant status of students. Teachers should maximize the student's dominant status. During the class presentation, if students make mistakes, the teachers should rectify with appropriate attitude and tone. Therefore, English course can not be taught as a knowledge lesson, but a communicative practice course. Only in this way can they dare to participate and be willing to participate.

\section{B. Implementing Measures of Situational Teaching Method}

1) Intuitive teaching method: The application of intuitive teaching method to create situation has three ways. They are material objects, pictures and body language. Material objects and pictures are used mainly for word teaching. We can use physical or toys to teach the words of fruits, vegetables, colors, animals and so on, while vivid pictures are also effective for those unavailable to find in real life. For example, teaching students the word "clean", the teacher can invite the girl to sweep the floor, and then ask the other students to guess what she is doing. Of course, it is very easy for them to understand that she is cleaning. At that time, teachers teach "clean" again. Students will build up the relation between the word and its meaning. With the help of props and body language, the students can obtain the knowledge more directly and have deeper impression. They won't forget the words easily because they get in touch with these things in their daily life. What's more, the drawing method is also a common method in primary English teaching. The teacher can draw some stick figures when teaching the word such as "dog" and "pig" and so on. The method is convenient for students to accept and understand.

2) The description method: This method refers to the teacher can create relevant situation with excellent voice and affection. It includes that teachers should have a good understanding about every passage and presents connotation with appropriate tone and intonation, which makes students have a better understanding about the passage. Besides that, it's natural that children in low of grade are deeply absorbed in stories. If the teacher turn the content into stories before the class, he would excite their curiosity, attract their attention, and guide them with interest to learn the stories that are linked with the contents.

3) The using of multimedia: Multimedia can bring both visual functions and acoustical functions into play by providing colorful pictures, interesting flashes and sounds.
With the help of multimedia, students can get better acquainted with Standard English. The English class is much more attractive if multimedia is properly used. Students will enjoy more freedom by observing and imaging. For instance, when teaching "the music instrument", teachers can search for some pictures from the internet, such as, drums, piano, violin and so on. These adoptions of multimedia aim to enliven the class atmosphere and help students assimilate new knowledge by means of vivid scenes. The application of multimedia technology in teaching, can change through the lively images to let the students' existing experience combine with the concept of association. Then establish the idea of abstract thinking and methods, to further deepen the understanding of knowledge and leave a deep impression in their minds. Therefore, teachers can get better effects by the multimedia and improve the quality of student's English.

4) The play method: The famous French educator once said: "The task of children is to play." the game will not only keep students active, but also makes input and output of language more creative and artistic. The teacher in the classroom thrust deep into games can make hard and boring words into easy and interesting words, mechanical word learning and drills into vivid and interesting. For example, to teacher the words of organs: ear, head, nose, cheek. The teacher can design such a game: the mosquito was biting me! The teacher copies the sound of the mosquito and yells out, "I got it ", and says " the mosquito was biting me!" then the teacher ask the students to guess where the mosquito is. The game should emphasize on the statements of the preposition and body parts, the students should ask and answer with complete sentences.

These kinds of activities use the students' interest points through the games. Students can have interest in the English learning by their own hands and their own thoughts. Searching and using the interest point can dissolve the teaching difficulty, and avoid the mechanical repetition. It will achieve the desired effect.

5) The song method: Many primary school English learning content can be expressed as songs, which helps to stimulate interests and dispersed the difficult points. Therefore, using the music and English together in English learning can help students to understand the dialogue, perform the content of the situation, create a sounding language environment, and make students blend in the situation naturally. In the singing process, students can ask and answer questions according to their songs or do a role play according to the conversations, which would reflect the communicative situation in the song, make the students free from the mechanical, stiff, dull and intense learning environment, eliminate learning fatigue, and feel the joy of learning and then improve their learning efficiency.

For example, in the English nursery rhyme "If you are happy, Clap your hands ", mainly contains the sentence 
pattern of "If you' re happy and you know it..." "clap your hands" "stomp your feet" and "shout hurray".

If you're happy and you know it, clap your hands

If you're happy and you know it clap your hands

If you're happy and you know it, then your face will surely show it

If you're happy and you know it, clap your hands

If you're happy and you know it, stomp your feet

If you're happy and you know it stomp your feet

If you're happy and you know it, then your face will surely show it

If you're happy and you know it, stomp your feet

If you're happy and you know it, shout hurray (hurray!)

If you're happy and you know it shout hurray (hurray!)

If you're happy and you know it, then your face will surely show it

If you're happy and you know it, shout hurray (hurray!)

If you're happy and you know it, do all three(hurray!)

If you're happy and you know it, do all three(hurray!)

If you're happy and you know it, then your face will surely show it

If you're happy and you know it, do all three (hurray!)

Due to English nursery rhymes comply with certain structural rules and strong sense of rhythm not only helps children to familiarize themselves with the rhythm of English, but also helps children learn and remember new words. Besides that, students can develop a sense of English and musicality.

\section{CONCLUSION}

To sum up, children begin to study English at primary school stage in Chinese. So, this is the critical stage for learning English. The situational approach is to improve the quality of primary school English and the students' learning activities in a good way. The implication of the primary school English teaching is to make the students have interest to learn, happy to learn, good at learning. Making full "use of learning" is an important way to expend teaching form, to cultivate and develop students' interest in English study; it is useful to improve our English teaching effect. In addition, the situational teaching method make students involved more actively in class rather than passively. The teacher's role has changed from purely teaching content to the guiding the students. And by such kind of means, better teaching method can be received by students. It also gets rid of the barriers of traditional teaching, makes a harmonious integration of teachers and students as a whole, and creates relaxing and vibrant atmosphere to inspire students' learning enthusiasm.

Based on the theoretical base of situational language teaching and features of primary students in foreign language learning, this paper lists the specific solutions to situational teaching method. There are some measures to create effective situation, such as intuitive teaching method, the description method, multimedia method, the play method, and the song method. The study results showed that situational teaching method is valuable to English learning and teaching. I hope there will be more empirical studies in the future on closer connection between language teaching and language research. Therefore, we should research further so as to provide more in depth theories to inspire primary school English teaching and learning.

\section{REFERENCES}

[1] Boyles, D. (2018). From Transmission to Transaction: John Dewey's Imaginative Vision of Teaching. Education,46(4).

[2] Brumfit. (1983). The Functional-Notional Approach: From Theory to Practice. New York: Gorsuch Scarisbrick Publishers.

[3] Charles, F. (1975). Teaching and Learning English as a Foreign Language. New York: Gorsuch Scarisbrick Press.

[4] Davies, Paul and E. Pearse. (2002). Success in English Teaching. Shanghai: Shanghai Foreign Language Education Press.

[5] Dewey, John. (1910). How We Think, New York: Dover Publications.

[6] Ding Wanzhen. (2018). The Importance of Situational Teaching in primary school English teaching. Middle School English, 12.

[7] Ellis, Rod. (1997). Understanding Second Language Acquisition. Shanghai: Shanghai Foreign Language Education Press.

[8] Finochiaro. (1975). The Foreign Language Learner: A Guide for Teachers. Regents Publishing Company.

[9] Geng Mei. (2018). How to Use Situational Teaching Method in Primary School English Teaching. Youth Diary, 2.

[10] Harmer, J. (2000). How to Teach English. Shanghai: Foreign Language Teaching and Research Press.

[11] Hedge, Tricia. (2002). Teaching and Learning in the Language Classroom. Shanghai: Shanghai Foreign Language Education Press.

[12] Hornby, A.S. (1950). Oxford Progressive English Course for Adult Learners. London: Oxford Universe Press.

[13] Howatt, A. P. R. (1999). A History of English Language Teaching. Shanghai: Shanghai Foreign Language Education Press.

[14] Johnson, Keith. (2007). An Introduction to Foreign Language Teaching. Beijing: Foreign Language Teaching and Research Press.

[15] Li Jilin. (2018). Experiment and Construction of Children's learning Situation Curriculum. Beijing: Foreign Language Teaching and Research Press.

[16] Normal Education Division of Ministry of Education. (2005). Li Jilin and Situation Education. Beijing: Beijing Normal University Press.

[17] Nunan, David. (2000). Designing Tasks for the Communicative Classroom. Beijing: People's Education Press.

[18] Richard, J C.\&Rodgers, T S. (1986). Approaches and Methods in Language Teaching: A Description and Analysis. New York: Cambridge University Press.

[19] She Gaoming. (2018). The Application of Situational Teaching Method in English Learning. China Juveniles, 15.

[20] Zhu Haiyan. (2006). Examples of Primary School English Game Teaching. Tianjin: Nankai University Press. 